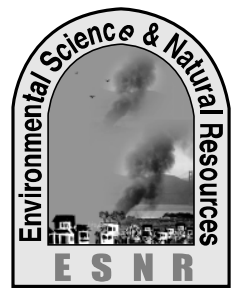

J. Environ. Sci. \& Natural Resources, 6(2): 55-59, 2013

ISSN 1999-7361

\title{
Effect of Fertilizers on Yield and Nutrient Uptake by Binadhan-7 Rice Grown in old Brahmaputra Floodplain Soils
}

\author{
R. R. Sarker, M. M. Ali, M. H. Rahman and M. K. Khan
}

Soil Science Division, Bangladesh Institute of Nuclear Agriculture, Mymensingh

\begin{abstract}
The economic rate of nutrients was determined with eight different fertilizer treatment applied on T. aman rice (var. Binadhan-7) in Old Brahmaputra Floodplain Soils (AEZ-9) during 2012 and 2013 at Trisal, Mymensingh. The experiment was laid out in a randomized complete block design (RCBD) with three replications. The treatment combinations were: $\mathrm{T}_{1}\left(\mathrm{~N}_{64} \mathrm{P}_{14} \mathrm{~K}_{28}\right.$ $\left.\mathrm{S}_{6} \mathrm{Zn}_{1}\right), \mathrm{T}_{2}\left(\mathrm{~N}_{80} \mathrm{P}_{14} \mathrm{~K}_{28} \mathrm{~S}_{6} \mathrm{Zn}_{1}\right), \mathrm{T}_{3}\left(\mathrm{~N}_{80} \mathrm{P}_{17.5} \mathrm{~K}_{28} \mathrm{~S}_{6} \mathrm{Zn}_{1}\right), \mathrm{T}_{4}\left(\mathrm{~N}_{80} \mathrm{P}_{14} \mathrm{~K}_{35} \mathrm{~S}_{6} Z_{1}\right), \mathrm{T}_{5}\left(\mathrm{~N}_{64} \mathrm{P}_{17.5} \mathrm{~K}_{35} \mathrm{~S}_{6} \mathrm{Zn}_{1}\right), \mathrm{T}_{6}\left(\mathrm{~N}_{80} \mathrm{P}_{17.5} \mathrm{~K}_{35} \mathrm{~S}_{6}\right.$ $\left.Z_{1}\right), T_{7}\left(N_{48} P_{10.5} K_{21} S_{4.5} Z_{0.75}\right)$, and $T_{8}$ (control). Grain and straw yields were significantly affected by the application of fertilizers at different rates. Results revealed that the average highest grain $\left(4.86 \mathrm{t} \mathrm{ha}^{-1}\right)$ was recorded in $\mathrm{T}_{6}\left(\mathrm{~N}_{80} \mathrm{P}_{17.5} \mathrm{~K}_{35} \mathrm{~S}_{6} \mathrm{Zn}_{1}\right)$ treatment and straw yield $\left(5.34 \mathrm{t} \mathrm{ha}^{-1}\right)$ was recorded in treatment $\mathrm{T}_{3}\left(\mathrm{~N}_{80} \mathrm{P}_{17.5} \mathrm{~K}_{28} \mathrm{~S}_{6} \mathrm{Zn}_{1}\right)$ which is $132.54 \%$ and $86.06 \%$ respectively higher over control treatment. The second highest grain yield $\left(4.77 \mathrm{t} \mathrm{ha}^{-1}\right)$ was obtained in $\mathrm{T}_{3}$ treatment and straw $\left(5.18 \mathrm{t} \mathrm{ha}^{-1}\right.$ ) was recorded in $\mathrm{T}_{6}$ treatment. Average (2012 \& 2013) nutrient uptake (grain and straw) was the highest in $\mathrm{T}_{3}$ treatment. Partial budget analysis demonstrated the highest net benefit of Tk. $69,673 \mathrm{ha}^{-1}$ in $\mathrm{T}_{6}$ followed by Tk. $68,833 \mathrm{ha}^{-1}$ in $\mathrm{T}_{3}$ and the highest MBCR (4.29) was obtained in $T_{3}$ treatment. The present investigation suggests that treatment $T_{3}\left(N_{80} P_{18} K_{28} S_{6}\right.$ $\mathrm{Zn}_{1}$ ) might be the best profitable fertilizers dose to sustain Binadhan-7 rice production in Old Brahmaputra Floodplain Soils.
\end{abstract}

Key words: AEZ-9, Binadhan-7, Fertilizers, T. aman season and Yield.

\section{Introduction}

Rice is the main staple food for above 150 million populations of the world. The current population growth rate is 2 million per year. According to this rate, the total population will become 233.2 million within 2050 (Bangladesh Economics Review, 2009). It's a tremendous challenge for providing food security to the increasing population. The diverse climatic phenomena like cyclone, drought, changing rainfall patterns and temperature has a significant role in food grain production. The impact of climate change on agriculture is global concerns and this is special for Bangladesh where lives and livelihoods depend mainly on agriculture. Binadhan-7 is a high yielding short duration (110-120 days) rice variety for transplanted aman season. Due to its short duration, rabi crops such as potato, mustard, and certain varieties of wheat, and some other crops can be planted after the harvest of early rice varieties, thus providing farmers an opportunity to plant more crops a year. Binadhan-7 is also used along with BRRIdhan 33 (115-120 days) to mitigate the suffering of MONGA affected farmers by fitting this rice variety to existing cropping pattern in the Northern Region of Bangladesh. There is no alternative, than to use more plant nutrients for high productivity (Ahmad, 1992). A huge quantity of nutrients removed from most of the floodplains and large portion of the terrace soils with the intensification of agriculture in Bangladesh. As a result the level of soil fertility is depleting gradually reflecting the needs of more fertilizer application in the soil for sustaining crop productivity. The application of fertilizers either in excess or less than optimum rate affect both yield and quality of rice to remarkable extent, hence proper management of crop nutrition is of immense importance (Nawaz, 2002; Meena et al. 2003). Therefore, to determine economic doses of fertilizers a field trial was done with $\mathrm{T}$. aman rice (var. Binadhan-7) in Old Brahmaputra Floodplain Soils (AEZ-9) at Trisal, Mymensingh.

\section{Materials and Methods}

Description of the experimental site, soil sampling and analysis

The experiment was conducted at T. aman (kharif II) season consecutively two years during 2012 and 2013 using Binadhan-7 rice to determine the economic rate of nutrients (N, P, K, S and Zn) in Old Brahmaputra Floodplain Soils at Trisal, Mymensingh. Before setting up of the experiment, initial soil sample was collected. After removal of weeds and stubbles, the sample was air dried, ground to pass through a 20 mesh sieve and stored in clean plastic bags for physical and chemical analysis. The soil sample was analyzed following standard methods viz. particle size distribution by a hydrometer, soil $\mathrm{pH}$ by glass electrode $\mathrm{pH}$ meter, organic matter by wet oxidation and total nitrogen by micro-Kjeldahl method, available phosphorus and available sulphur were extracted from soil by dilute acid solutions and determined by a spectrophotometer, exchangeable potassium was extracted with ammonium acetate solution and was determined by a flame photometer. The soil of the experimental plot was clayey in texture and slightly acidic in reaction. The total nitrogen and available phosphorus contents were very low, exchangeable potassium content was low and available sulphur content was medium in the experimental plot. 


\section{Transplanting, fertilization and intercultural operations}

The experiment was laid out in a randomized complete block design (RCBD) with eight treatments and three replications. The unit plot size was $5 \mathrm{~m} \mathrm{x}$ $4 \mathrm{~m}$. Before transplantation the land was well ploughed following laddering. The fertilizer treatments were: $\mathrm{T}_{1}\left(\mathrm{~N}_{64} \mathrm{P}_{14} \mathrm{~K}_{28} \mathrm{~S}_{6} \mathrm{Zn}_{1}\right), \mathrm{T}_{2}\left(\mathrm{~N}_{80} \mathrm{P}_{14}\right.$ $\left.\mathrm{K}_{28} \mathrm{~S}_{6} \mathrm{Zn}_{1}\right), \mathrm{T}_{3}\left(\mathrm{~N}_{80} \mathrm{P}_{17.5} \mathrm{~K}_{28} \mathrm{~S}_{6} \mathrm{Zn}_{1}\right), \mathrm{T}_{4}\left(\mathrm{~N}_{80} \mathrm{P}_{14} \mathrm{~K}_{35}\right.$ $\left.\mathrm{S}_{6} \mathrm{Zn}_{1}\right), \mathrm{T}_{5}\left(\mathrm{~N}_{64} \mathrm{P}_{17.5} \mathrm{~K}_{35} \mathrm{~S}_{6} \mathrm{Zn}_{1}\right), \mathrm{T}_{6}\left(\mathrm{~N}_{80} \mathrm{P}_{17.5} \mathrm{~K}_{35} \mathrm{~S}_{6}\right.$ $\left.Z_{1}\right), T_{7}\left(N_{48} P_{10.5} K_{21} S_{4.5} Z_{0.75}\right)$, and $T_{8}$ (control). Three healthy seedlings of 20-days of Binadhan-7 rice were transplanted per hill in the plots on 28 July, 2012 and 29 July, 2013 respectively. Fertilizer applied to each plot as per treatments. Entire amount of TSP, MoP, gypsum and zinc sulphate were applied as basal at the time of final land preparation. Urea was applied in two equal installments on the $4^{\text {th }}$ and $7^{\text {th }}$ week (i.e. about 25 days and 45 days) after transplanting. Gap filling was done on the $2^{\text {nd }}$ week (i.e. about 10 days) after transplanting to make uniform plant population density for each treatment. Weeding was done three times at $2^{\text {nd }}, 4^{\text {th }}$ and $7^{\text {th }}$ week (i.e. about 10, 25 and 45 days) after transplanting of the seedlings. Spraying was done whenever necessary. The crop of Binadhan-7 rice was harvested on 25 October, 2012 and 30 October, 2013 respectively. Data on yield contributing characters were recorded from ten randomly selected plants per hill from each plot. The grain and straw samples were stored for chemical analysis.

\section{Chemical analysis of grain and straw samples}

The grain and straw samples were analyzed for the determination of $\mathrm{N}, \mathrm{P}, \mathrm{K}$ and $\mathrm{S}$ contents. The samples were dried in an oven at about $65^{\circ} \mathrm{C}$ for 48 hours and then ground in a grinding mill to pass through a 20 mesh sieve. The ground grain and straw samples were stored in small paper bags and placed in desiccators for the analysis of different elements.

For nitrogen determination, $0.50 \mathrm{~g}$ of oven dried ground plant sample was taken in a micro-Kjeldahl flask. $1.10 \mathrm{~g}$ of catalyst mixture $\left(\mathrm{K}_{2} \mathrm{SO}_{4}: \mathrm{CUSO}_{4}\right.$ : $5 \mathrm{H}_{2} 0$ : Se powder =100: 10: 1), $3 \mathrm{ml}$ of $30 \% \mathrm{HClO}_{4}$ and $5 \mathrm{ml}$ of conc. $\mathrm{H}_{2} \mathrm{SO}_{4}$ were added to the flask. The flask was swirled and allowed to stand for about 1.5-2 hours. Then the flask was heated on an electric hot plate for heating at $150^{\circ} \mathrm{C}$ and continued until the digest become colorless. After cooling the digest was transferred into a $100 \mathrm{ml}$ volumetric flask and the volume was made up to the mark with distilled water. A reagent blank was prepared similarly. From the digests, nitrogen was determined.

$0.50 \mathrm{~g}$ oven-dried, ground samples (straw or grain) was taken in a digestion flask. $8 \mathrm{ml}$ of di-acid mixture
$\left(\mathrm{HNO}_{3}: \mathrm{HClO}_{4}\right.$ in the ratio 5:3) was added into flask and kept for 1 hour. Then the flask was heated on an electric hot plate for heating at $150^{\circ} \mathrm{C}$ and continued until the digest become colorless. After cooling the digest was transferred into a $50 \mathrm{ml}$ volumetric flask and the volume was made up to mark with distilled water. From the digests $\mathrm{P}, \mathrm{K}$ and $\mathrm{S}$ contents were determined.

\section{Statistical analysis}

The data were statistically analyzed on various plant characters with the help of a MSTAT program and mean differences were compared by Duncan's Multiple Range Test (Gomez and Gomez, 1984).

\section{Result and Discussion}

\section{Yield contributing characters}

Yield contributing characters were influenced by different treatments (Table 1). Plant height was significantly varied among the treatments in both years of 2012 and 2013. In 2012, plant height of all the treatments was statistically similar except $\mathrm{T}_{8}$. In 2013, the highest plant height $(94.13 \mathrm{~cm})$ was obtained in treatment $T_{5}$. Treatment $T_{3}, T_{7}$ and $T_{8}$ produced the lowest and statistically similar plant height. Faraji et al. (1998) reported that plant height increased with an increase in the rate of fertilizer application.

The different treatment combinations of fertilizers significantly influenced the panicle length in 2012 year. The highest panicle length $(24.27 \mathrm{~cm})$ was found in $\mathrm{T}_{6}$ followed by $\mathrm{T}_{3}$ and lowest panicle length was found in $\mathrm{T}_{8}$ (control). Panicle length was not significantly varied among the treatments in 2013 . Manzoor et al. (2006) found highest panicle length $(29.75 \mathrm{~cm})$ at $225 \mathrm{Kg} \mathrm{N}$ per hectare level.

Number of effective tiller varied significantly under different treatments in both years. Treatment $T_{5}$ produced the highest number of effective tiller (12.87) and lowest number (9.80) was found in $\mathrm{T}_{8}$ in 2012. Treatment $T_{2}$ produced the highest (14.00) number of effective tillers per hill and $\mathrm{T}_{1}$ produced the second highest (13.93) and the lowest (6.80) was found in control treatment in 2013. Manzoor et al. (2006) observed maximum number of productive tillers per hill (23.42) at $225 \mathrm{Kg} \mathrm{N}$ per hectare.

The highest 1000 grain weight $(24.02 \mathrm{~g})$ was found in $\mathrm{T}_{3}$ and the lowest $(21.64 \mathrm{~g})$ was found in treatment $\mathrm{T}_{8}$ in 2012. In 2013, $\mathrm{T}_{6}$ produced the highest $(22.67 \mathrm{~g})$ 1000 grain weight and the other treatments were statistically similar. Similar results of plant height, number of effective tillers and 1000 grain weight were also observed by Quddus et al. (2012). 
Table 1. The effects of different treatments on yield parameters of Binadhan-7 during 2012 and 2013 at Trisal, Mymensingh

\begin{tabular}{|c|c|c|c|c|c|c|c|c|}
\hline \multirow[b]{2}{*}{ Treatments } & \multicolumn{4}{|c|}{2012} & \multicolumn{4}{|c|}{2013} \\
\hline & $\begin{array}{l}\text { Plant } \\
\text { height } \\
(\mathrm{cm})\end{array}$ & $\begin{array}{l}\text { Panicle } \\
\text { length } \\
(\mathrm{cm})\end{array}$ & $\begin{array}{l}\text { Tillers/hill } \\
\text { (no) }\end{array}$ & $\begin{array}{l}\text { 1000seed } \\
\text { weight }(\mathrm{g})\end{array}$ & $\begin{array}{l}\text { Plant } \\
\text { height } \\
(\mathrm{cm})\end{array}$ & $\begin{array}{l}\text { Panicle } \\
\text { length }(\mathrm{cm})\end{array}$ & $\begin{array}{l}\text { Tillers/hill } \\
\text { (no) }\end{array}$ & $\begin{array}{l}1000 \text { seed } \\
\text { weight }(\mathrm{g})\end{array}$ \\
\hline $\mathrm{T}_{1}\left(\mathrm{~N}_{64} \mathrm{P}_{14} \mathrm{~K}_{28} \mathrm{~S}_{6} \mathrm{Zn}_{1}\right)$ & $91.87 \mathrm{a}$ & $23.40 \mathrm{bc}$ & $11.47 \mathrm{bc}$ & $22.62 b c$ & $92.47 \mathrm{ab}$ & 23.00 & $13.93 a$ & $20.85 b$ \\
\hline $\mathrm{T}_{2}\left(\mathrm{~N}_{80} \mathrm{P}_{14} \mathrm{~K}_{28} \mathrm{~S}_{6} \mathrm{Zn}_{1}\right)$ & $92.73 a$ & $23.27 \mathrm{c}$ & $11.07 \mathrm{bcd}$ & $23.19 \mathrm{ab}$ & $92.4 \mathrm{ab}$ & 22.13 & $14.00 \mathrm{a}$ & $21.05 \mathrm{~b}$ \\
\hline $\mathrm{T}_{3}\left(\mathrm{~N}_{80} \mathrm{P}_{17.5} \mathrm{~K}_{28} \mathrm{~S}_{6} \mathrm{Zn}_{1}\right)$ & $94.20 \mathrm{a}$ & $24.20 \mathrm{a}$ & 10.60cde & $24.02 \mathrm{a}$ & $89.13 c$ & 22.13 & $10.60 b c$ & 21.11ab \\
\hline $\mathrm{T}_{4}\left(\mathrm{~N}_{80} \mathrm{P}_{14} \mathrm{~K}_{35} \mathrm{~S}_{6} \mathrm{Zn}_{1}\right)$ & $93.67 \mathrm{a}$ & $23.20 \mathrm{c}$ & $11.80 \mathrm{~b}$ & $23.20 \mathrm{ab}$ & $90.87 \mathrm{bc}$ & 22.40 & $10.27 b c$ & $22.02 \mathrm{ab}$ \\
\hline $\mathrm{T}_{5}\left(\mathrm{~N}_{64} \mathrm{P}_{17.5} \mathrm{~K}_{35} \mathrm{~S}_{6} \mathrm{Zn}_{1}\right)$ & $94.00 \mathrm{a}$ & $24.07 \mathrm{ab}$ & $12.87 \mathrm{a}$ & $22.00 \mathrm{c}$ & $94.13 \mathrm{a}$ & 23.27 & $9.60 \mathrm{c}$ & $21.54 \mathrm{ab}$ \\
\hline $\mathrm{T}_{6}\left(\mathrm{~N}_{80} \mathrm{P}_{17.5} \mathrm{~K}_{35} \mathrm{~S}_{6} \mathrm{Zn}_{1}\right)$ & $93.07 \mathrm{a}$ & $24.27 \mathrm{a}$ & $11.60 \mathrm{~b}$ & $22.80 \mathrm{bc}$ & $93.67 \mathrm{a}$ & 22.73 & $12.47 \mathrm{ab}$ & $22.67 \mathrm{a}$ \\
\hline $\mathrm{T}_{7}\left(\mathrm{~N}_{48} \mathrm{P}_{10.5} \mathrm{~K}_{21} \mathrm{~S}_{4.5} \mathrm{Zn}_{0.75}\right)$ & $92.27 \mathrm{a}$ & $22.67 \mathrm{c}$ & $10.33 \mathrm{de}$ & $22.00 \mathrm{c}$ & $89.87 \mathrm{c}$ & 22.87 & $11.27 b c$ & $20.96 b$ \\
\hline $\mathrm{T}_{8}$ (Control) & $87.87 \mathrm{~b}$ & $21.60 d$ & $9.80 \mathrm{e}$ & $21.64 \mathrm{c}$ & $89.33 c$ & 22.93 & $6.80 \mathrm{~d}$ & $20.16 b$ \\
\hline $\mathrm{CV}(\%)$ & 1.96 & 1.84 & 4.23 & 2.71 & 3.29 & 2.89 & 11.98 & 6.33 \\
\hline
\end{tabular}

In a column, same letter (s) are not significantly different at $5 \%$ level, $\mathrm{CV}=$ Coefficient of variation

\section{Grain and straw yields}

The grain and straw yields of Binadhan-7 were significantly influenced by application of fertilizers (Table 2). The highest grain yield $\left(4.93 \mathrm{t} \mathrm{ha}^{-1}\right)$ was found in treatment $\mathrm{T}_{5}$ and the lowest $\left(2.06 \mathrm{t} \mathrm{ha}^{-1}\right)$ was found in $\mathrm{T}_{8}$ in 2012. In 2013, treatment $\mathrm{T}_{6}$ produced the highest grain yield $\left(5.02 \mathrm{t} \mathrm{ha}^{-1}\right)$ which was statistically similar to $T_{3}$. Treatment $T_{8}$ produced the lowest grain yield $\left(2.11 \mathrm{t} \mathrm{ha}^{-1}\right)$. The average highest grain yield $\left(4.86 \mathrm{t} \mathrm{ha}^{-1}\right)$ was found in $\mathrm{T}_{6}$ followed by $\mathrm{T}_{3}$ treatment $\left(4.77 \mathrm{t} \mathrm{ha}^{-1}\right)$ and the lowest yield $(2.09 \mathrm{t}$ $\mathrm{ha}^{-1}$ ) was found in $\mathrm{T}_{8}$ treatment. Adhikary and Rahman (1996) reported that the highest rice grain yield was obtained from $100 \mathrm{~kg} \mathrm{~N} \mathrm{ha}^{-1}\left(4.25 \mathrm{t} \mathrm{ha}^{-1}\right)$. Idris and Matin (1990) observed that grain yield increased gradually with an increase in $\mathrm{N}$ levels up to
$120 \mathrm{~kg} \mathrm{ha}^{-1}$. Manzoor et al. (2006) obtained maximum paddy yield $\left(4.24 \mathrm{t} \mathrm{ha}^{-1}\right)$ from $175 \mathrm{Kg} \mathrm{N}$ per ha.

The highest straw yield $\left(5.20 \mathrm{tha}^{-1}\right)$ was found in $\mathrm{T}_{6}$ and the lowest $\left(2.64 \mathrm{tha}^{-1}\right)$ was found in $\mathrm{T}_{8}$ treatment in 2012. In 2013, treatment $T_{6}$ produced the highest straw yield $\left(5.88 \mathrm{tha}^{-1}\right)$ and treatment $\mathrm{T}_{8}$ produced the lowest straw yield $\left(3.10 \mathrm{t} \mathrm{ha}^{-1}\right)$. The average highest straw (5.34 $\mathrm{t} \mathrm{ha}^{-1}$ ) was found in $\mathrm{T}_{3}$ treatment and the lowest $\left(2.87 \mathrm{t} \mathrm{ha}^{-1}\right)$ was found in $\mathrm{T}_{8}$. Sheikh et al. (2009) found the highest grain $\left(5.30 \mathrm{tha}^{-1}\right)$ and straw $\left(6.55 \mathrm{t} \mathrm{ha}^{-1}\right)$ of $\mathrm{T}$. aman rice against treatment $\mathrm{T}_{2}$ (120-36-70-10 kg NPKS per hectare).

Table 2. The effects of different treatments on the grain and straw yields $\left(t \mathrm{ha}^{-1}\right)$ of Binadhan-7 at Trisal, Mymensingh

\begin{tabular}{|c|c|c|c|c|c|c|}
\hline \multirow[t]{2}{*}{ Treatments } & \multicolumn{2}{|c|}{2012} & \multicolumn{2}{|c|}{2013} & \multicolumn{2}{|c|}{ Average } \\
\hline & Grain & Straw & Grain & Straw & Grain & Straw \\
\hline $\mathrm{T}_{1}\left(\mathrm{~N}_{64} \mathrm{P}_{14} \mathrm{~K}_{28} \mathrm{~S}_{6} \mathrm{Zn}_{1}\right)$ & $4.03 \mathrm{bc}$ & $4.66 \mathrm{c}$ & $4.20 \mathrm{c}$ & $5.10 \mathrm{bc}$ & 4.11 & 4.88 \\
\hline $\mathrm{T}_{2}\left(\mathrm{~N}_{80} \mathrm{P}_{14} \mathrm{~K}_{28} \mathrm{~S}_{6} \mathrm{Zn}_{1}\right)$ & $4.34 \mathrm{ab}$ & $4.95 b$ & $4.68 \mathrm{ab}$ & $5.41 \mathrm{abc}$ & 4.51 & 5.18 \\
\hline $\mathrm{T}_{3}\left(\mathrm{~N}_{80} \mathrm{P}_{17.5} \mathrm{~K}_{28} \mathrm{~S}_{6} \mathrm{Zn}_{1}\right)$ & $4.67 \mathrm{ab}$ & $5.13 \mathrm{a}$ & $4.87 \mathrm{a}$ & $5.54 \mathrm{ab}$ & 4.77 & 5.34 \\
\hline $\mathrm{T}_{4}\left(\mathrm{~N}_{80} \mathrm{P}_{14} \mathrm{~K}_{35} \mathrm{~S}_{6} \mathrm{Zn}_{1}\right)$ & $4.70 \mathrm{ab}$ & $4.07 \mathrm{e}$ & $4.50 \mathrm{bc}$ & $4.98 \mathrm{c}$ & 4.60 & 4.53 \\
\hline $\mathrm{T}_{5}\left(\mathrm{~N}_{64} \mathrm{P}_{17.5} \mathrm{~K}_{35} \mathrm{~S}_{6} \mathrm{Zn}_{1}\right)$ & $4.93 \mathrm{a}$ & $5.19 \mathrm{a}$ & $4.30 \mathrm{c}$ & $4.48 \mathrm{~d}$ & 4.62 & 4.84 \\
\hline $\mathrm{T}_{6}\left(\mathrm{~N}_{80} \mathrm{P}_{17.5} \mathrm{~K}_{35} \mathrm{~S}_{6} \mathrm{Zn}_{1}\right)$ & $4.70 \mathrm{ab}$ & $4.50 \mathrm{~d}$ & $5.02 \mathrm{a}$ & $5.88 \mathrm{a}$ & 4.86 & 5.18 \\
\hline $\mathrm{T}_{7}\left(\mathrm{~N}_{48} \mathrm{P}_{10.5} \mathrm{~K}_{21} \mathrm{~S}_{4.5} \mathrm{Zn}_{0.75}\right)$ & $3.46 \mathrm{c}$ & $5.20 \mathrm{a}$ & $3.52 \mathrm{~d}$ & $4.15 \mathrm{~d}$ & 3.49 & 4.68 \\
\hline $\mathrm{T}_{8}$ (Control) & $2.06 \mathrm{~d}$ & $2.64 \mathrm{f}$ & $2.11 \mathrm{e}$ & $3.10 \mathrm{e}$ & 2.09 & 2.87 \\
\hline $\mathrm{CV}(\%)$ & 10.51 & 1.54 & 5.75 & 5.37 & - & - \\
\hline
\end{tabular}

Same letter (s) in the column are not statistically significant at $5 \%$ level, CV $=$ Coefficient of variation 


\section{Total Nutrient uptake}

The highest average $\mathrm{N}$ uptake $\left(97.4 \mathrm{~kg} \mathrm{ha}^{-1}\right)$ was recorded in treatment $\mathrm{T}_{3}$ and the lowest $\mathrm{N}$ uptake (36.62 $\mathrm{kg} \mathrm{ha}^{-1}$ ) was found in treatment $\mathrm{T}_{8}$. The result showed that the total $\mathrm{N}$ uptake in rice was more prominent due to combined application of fertilizers (Table 3). Quddus et al. (2012) reported that total N content was higher with application of $130 \mathrm{Kg} \mathrm{N}$ per hectare in T. aman rice.

The highest average $\mathrm{P}$ uptake of $14.11 \mathrm{~kg} \mathrm{ha}^{-1}$ was obtained in treatment $\mathrm{T}_{3}$ and the lowest $\mathrm{P}$ uptake of
$4.94 \mathrm{~kg} \mathrm{ha}^{-1}$ was observed in treatment $\mathrm{T}_{8}$ (control). Kadu et al. (1991) reported that grain $\mathrm{P}$ and $\mathrm{K}$ were the highest with NPK + FYM application.

The highest average $\mathrm{K}$ uptake $\left(108.5 \mathrm{~kg} \mathrm{ha}^{-1}\right)$ was obtained in treatment $\mathrm{T}_{3}$. The lowest average $\mathrm{K}$ uptake $\left(42.4 \mathrm{~kg} \mathrm{ha}^{-1}\right)$ was observed in treatment $\mathrm{T}_{8}$ (control). Islam et al. (2010) reported that the highest $\mathrm{K}$ uptake by both grain and straw was obtained from $\mathrm{T}_{7}$ treatment and lowest from control in rice crop.

Table 3. Effect of fertilizers on the average (2012 and 2013) nutrient uptake (grain and straw) by Binadhan-7 at Trisal, Mymensingh

\begin{tabular}{lcccc}
\hline \multirow{2}{*}{ Treatment } & \multicolumn{4}{c}{ Average nutrient uptake by Binadhan-7 $\left(\mathrm{kg} \mathrm{ha}^{-1}\right)$} \\
\cline { 2 - 5 } & $\mathrm{N}$ & $\mathrm{P}$ & $\mathrm{K}$ & $\mathrm{S}$ \\
\hline $\mathrm{T}_{1}\left(\mathrm{~N}_{64} \mathrm{P}_{14} \mathrm{~K}_{28} \mathrm{~S}_{6} \mathrm{Zn}_{1}\right)$ & 74.02 & 8.91 & 91.65 & 5.66 \\
$\mathrm{~T}_{2}\left(\mathrm{~N}_{80} \mathrm{P}_{14} \mathrm{~K}_{28} \mathrm{~S}_{6} \mathrm{Zn}_{1}\right)$ & 87.50 & 10.97 & 95.24 & 6.79 \\
$\mathrm{~T}_{3}\left(\mathrm{~N}_{80} \mathrm{P}_{17.5} \mathrm{~K}_{28} \mathrm{~S}_{6} \mathrm{Zn}_{1}\right)$ & 97.40 & 14.11 & 108.5 & 6.40 \\
$\mathrm{~T}_{4}\left(\mathrm{~N}_{80} \mathrm{P}_{14} \mathrm{~K}_{35} \mathrm{~S}_{6} \mathrm{Zn}_{1}\right)$ & 89.12 & 11.37 & 91.59 & 5.79 \\
$\mathrm{~T}_{5}\left(\mathrm{~N}_{64} \mathrm{P}_{17.5} \mathrm{~K}_{35} \mathrm{~S}_{6} \mathrm{Zn}_{1}\right)$ & 84.39 & 12.08 & 86.16 & 5.94 \\
$\mathrm{~T}_{6}\left(\mathrm{~N}_{80} \mathrm{P}_{17.5} \mathrm{~K}_{35} \mathrm{~S}_{6} Z_{1}\right)$ & 90.39 & 12.70 & 102.62 & 6.57 \\
$\mathrm{~T}_{7}\left(\mathrm{~N}_{48} \mathrm{P}_{10.5} \mathrm{~K}_{21} \mathrm{~S}_{4.5} Z_{0.75}\right)$ & 67.39 & 8.34 & 75.89 & 5.10 \\
$\mathrm{~T}_{8}$ (Control) & 36.62 & 4.94 & 42.40 & 2.98 \\
\hline
\end{tabular}

The highest amount of average $S$ uptake of $6.79 \mathrm{~kg}$ $\mathrm{ha}^{-1}$ was found in treatment $\mathrm{T}_{2}$ and the lowest average $\mathrm{S}$ uptake of $2.98 \mathrm{~kg} \mathrm{ha}^{-1}$ was observed in $\mathrm{T}_{8}$ (control). Islam et al. (1997) reported that application of $\mathrm{S}$ significantly increased $S$ uptake by rice. This result correlated well with the works of Xie and Mamaril (1992) who observed a significant $\mathrm{S}$ uptake by rice plant due to $\mathrm{S}$ application.

\section{Economics of fertilizers use}

The results of partial budget analysis of Binadhan-7 (Table 4) showed that the highest net benefit of Tk. $69,673 \mathrm{ha}^{-1}$ was obtained in $\mathrm{T}_{6}$ followed by $\mathrm{Tk}$. 68,833 in $T_{3}$ treatment. The marginal benefit cost ratio (MBCR) also demonstrated against the treatments. The highest MBCR of 4.29 was obtained in $\mathrm{T}_{3}$ followed by 4.22 in $\mathrm{T}_{6}$ treatment.

Table 4. Partial budget analysis of fertilizer use

\begin{tabular}{lccccc}
\hline Treatments & $\begin{array}{c}\text { Gross return } \\
\text { (Tk.) }\end{array}$ & $\begin{array}{c}\text { Fert. cost } \\
\text { (Tk.) }\end{array}$ & $\begin{array}{c}\text { Net return } \\
\text { (Tk.) }\end{array}$ & $\begin{array}{c}\text { Marginal } \\
\text { return (Tk.) }\end{array}$ & $\begin{array}{c}\text { MBCR } \\
\end{array}$ \\
\hline $\mathrm{T}_{1}\left(\mathrm{~N}_{64} \mathrm{P}_{14} \mathrm{~K}_{28} \mathrm{~S}_{6} \mathrm{Zn}_{1}\right)$ & 66530 & 6812 & 59718 & 25498 & 3.74 \\
$\mathrm{~T}_{2}\left(\mathrm{~N}_{80} \mathrm{P}_{14} \mathrm{~K}_{28} \mathrm{~S}_{6} \mathrm{Zn}_{1}\right)$ & 72830 & 7532 & 65298 & 31078 & 4.13 \\
$\mathrm{~T}_{3}\left(\mathrm{~N}_{80} \mathrm{P}_{17.5} \mathrm{~K}_{28} \mathrm{~S}_{6} \mathrm{Zn}_{1}\right)$ & 76890 & 8057 & 68833 & 34613 & 4.29 \\
$\mathrm{~T}_{4}\left(\mathrm{~N}_{80} \mathrm{P}_{14} \mathrm{~K}_{35} \mathrm{~S}_{6} \mathrm{Zn}_{1}\right)$ & 73530 & 7882 & 65648 & 31428 & 3.99 \\
$\mathrm{~T}_{5}\left(\mathrm{~N}_{64} \mathrm{P}_{17.5} \mathrm{~K}_{35} \mathrm{~S}_{6} \mathrm{Zn}_{1}\right)$ & 74140 & 7687 & 66453 & 32233 & 4.19 \\
$\mathrm{~T}_{6}\left(\mathrm{~N}_{80} \mathrm{P}_{17.5} \mathrm{~K}_{35} \mathrm{~S}_{6} \mathrm{Zn}_{1}\right)$ & 78080 & 8407 & 69673 & 35453 & 4.22 \\
$\mathrm{~T}_{7}\left(\mathrm{~N}_{48} \mathrm{P}_{10.5} \mathrm{~K}_{21} \mathrm{~S}_{4.5} \mathrm{Zn}_{0.75}\right)$ & 57030 & 5134.5 & 51895.5 & 17675.5 & 3.44 \\
$\mathrm{~T}_{8}(\mathrm{Control})$ & 34220 & 0 & 34220 & - & - \\
\hline
\end{tabular}

Grain $=15$ Tk. $\mathrm{Kg}^{-1} ;$ Straw $=1 \mathrm{Tk} . \mathrm{kg}^{-1} ; \mathrm{N}=45 \mathrm{Tk} . \mathrm{kg}^{-1} ; \mathrm{P}=150 \mathrm{Tk} . \mathrm{kg}^{-1} ; \mathrm{K}=50 \mathrm{Tk} . \mathrm{kg}^{-1} ; \mathrm{S}=55 \mathrm{Tk} . \mathrm{kg}^{-1}$ and Zn $=102 \mathrm{Tk} . \mathrm{kg}-$ ${ }^{1}, \mathrm{MBCR}=$ Marginal benefit cost ratio.

\section{Conclusion}

Application of $\mathrm{N}_{80} \mathrm{P}_{18} \mathrm{~K}_{28} \mathrm{~S}_{6} \mathrm{Zn}_{1}$ fertilizers is economically more profitable for Binadhan-7 production than any other combinations. Thus, this combination of fertilizers may be recommended for higher yield of Binadhan-7 rice and sustaining soil fertility. 


\section{Acknowledgement}

The authors gratefully acknowledged the financial support for this study under a Coordinated Project on Soil Fertility and Fertilizer Management for Crops and Cropping Patterns: BINA component of Sponsored Public Goods Research (SPGR), PIUBARC, NATP: phase-1.

\section{References}

Adhikary, R. C. and Rahman, H. 1996. Effect of different doses of nitrogen on the yield of BRII variety of rice. In variety, Fertilizer and Weedicide Trial of some Field Crops. Rural Development Academy. Bogra, pp 15-20.

Ahmad, N. 1992. Efficient use of plant nutrients. Proc.4th National Cong. Soil Soci., 2:22.

Bangladesh Economics Review, 2009. Government of the People's Republic of Bangladesh. Ministry of Finance, Dhaka.

Faraji, A. and Mirlohi, A. 1998. Effect of splitting and rates of nitrogen application on yield and yield components of rice in Isfahan. J. Agric. Sci. Natural Res., 2(3): 25-34.

Gomez, K. A. and Gomez, A. A. 1984. Statistical procedures for agricultural research (second edition). An International Rice Research Institute Book. John Wiley \& Sons, Inc., USA.

Idris and Matin, M. A.1990. Response of four exotic strains of aman rice to urea. Bangladesh $J$. Agril. Sci., 17(2): 271-275.

Islam, M. R.; Rasat, T. M. and Jahiruddin. 1997. Direet and residual effects of S. Zn and B on yield and nutrient uptake in a rice mustard cropping systen. J. Indian Soc. Soil Sci., 45, 126-129.

Islam, M. S.; Islam, M. Z.; Rahman, G. K. M. M. and Chowdhury, M. A. A. H. 2010. Effect of some secondary and micro nutrients along with organic amendments on T. aman. Int. $J$. Sustain. Crop Prod., 5(4): 51-58.
Kadu, P. B.; Bhoyar, V. S.; and Thakare,R. S. 1991. Effect of NPK-FYM blended manuring mixtures on performance of rice. J. Soils Crops., 1(2): 172-174.

Manzoor, Z.; Awan, T.H.; Zahid, M.A. and Faiz, F. 2006. Response of rice crop (Super Basmati) to different nitrogen levels. J. Animal Plant Sci., 16(1/2): 52-55.

Meena, S. L.; Surendra, S.; Shivay, Y. S and Singh, S. 2003. Response of hybrid rice (Oryza sativa) to nitrogen and potassium application in sandy clay loam soils. Indian J. Agric. Sci., 73(1): 8-11.

Nawaz, H. M. A. 2002. Effect of various levels and methods of nitrogen application on nitrogen use efficiency in rice (Super Basmati.) M.Sc. Thesis (Unpublished), Deptt. Agron, Univ. Agric., Faisalabad.

Quddus, M. A.; Rashid. M. H.; Hossain, M. A.; Naser, H. M. and Mian. J. A. 2012. Integrated nutrient management for sustaining soil fertility through chickpeamungbean- T.aman cropping pattern at Madaripur region. Bangladesh J. Agril. Res., 37(2): 251-262.

Sheikh, M. H. R.; Khan, M.S.; Hannan, A.; Huda, A. and Rahman, M. T. 2009. Sustainable crop production retaining soil fertility and environment through Mustard-MungbeanT.aman cropping pattern. J. Soil. Nature,. 3(2): 10-14.

Xie, L. S. and Mamaril, C. P. 1992. Oxidation and management of elemental sulphur in lowland rice soils. Proc. Int. symp. paddy soils, Narjing, Chuna. 15-19 September, 205-206. 